Artikel Penelitian

\title{
Distribusi Fraktur Femur Yang Dirawat Di Rumah Sakit Dr.M.Djamil, Padang (2010-2012)
}

Vithiya Chandra Sagaran ${ }^{1}$, Menkher Manjas ${ }^{2}$, Rosfita Rasyid ${ }^{3}$

\begin{abstract}
Abstrak
Fraktur adalah suatu diskontinuitas susunan tulang yang disebabkan oleh trauma atau keadaan patologis. Kecelakaan lalu-lintas merupakan pembunuh nomor tiga di Indonesia, setelah penyakit jantung koroner dan tuberkulosis. Salah satu insiden kecelakaan yang memiliki prevalensi cukup tinggi adalah fraktur pada femur. Tujuan penelitian ini adalah untuk mengetahui distribusi fraktur femur yang dirawat di rumah sakit Dr. M. Djamil, Padang periode 2010 hingga 2012. Penelitian dilakukan dengan pendekatan deskriptif mengunakan rekam medik pasien fraktur femur. Data penelitian disajikan dalam bentuk table distribusi frekuensi. Hasil dari penelitian ini didapatkan fraktur femur banyak terjadi pada laki-laki usia 17-25 tahun dan penyebab terbanyak adalah cedera traumatik seperti kecelakaan. Fraktur femur banyak terjadi di bagian medial femur dan merupakan fraktur tertutup. Penanganan fraktur femur dirawat dengan operasi iaitu reduksi fiksasi internal terbuka.
\end{abstract}

Kata kunci: fraktur femur, kecelakaan, keadaan patologis, reduksi fiksasi internal

\section{Abstract}

Fracture is discontinuity of bone tissues and or cartilages which caused by traumatic injuries or pathologic conditions. Road accidents are the number three killer in Indonesia after coronary heart diseases and tuberculosis. Road accidents have higher incidence for femur fractures. The objective of this study was to determine the distribution of femur fractures treated in Dr.M.Djamil Hospital, Padang in year 2010-2012. This research was conducted in descriptive approach using the medical record of the patients treated for femur fracture. The data was processed manually using frequency distribution tables. The result of this research are femur fractures happens to male age of 17-25 years old and most caused by traumatic injuries such as road accidents. Most femur fractures happened on the medial shaft and are closed fractures. Fractures mostly treated by operations which is open reduction internal fixation. Keywords: femur fractures, road accidents, pathologic conditions, open reduction internal fixation

Affiliasi penulis: 1. Prodi Profesi Dokter FK Unand (Fakultas Kedokteran Universitas Andalas Padang), 2. Bagian Bedah Orthopedi FK Unand/RS Dr.M.Djamil Padang, 3. Bagian IImu Kesehatan Masyarakat FK Unand.

Korespondensi: Vithiya Chandra Sagaran,

Email:vithiyarani@yahoo.com, Telp: +6287895074407

\section{PENDAHULUAN}

Fraktur adalah suatu diskontinuitas susunan tulang yang disebabkan oleh trauma atau keadaan patologis. ${ }^{1}$ Fraktur adalah terputus kontinuitas jaringan tulang dan atau rawan yang umumnya disebabkan oleh rudapaksa. $^{2}$
World Health Organization (WHO) telah menetapkan dekade (2000-2009) menjadi dekade tulang dan persendian. ${ }^{3}$ Penyebab fraktur terbanyak adalah karena kecelakaan lalulintas seperti kecelakaan motor dan mobil serta kecelakaan pejalan kaki sewaktu menyebrang. Data dinas Kesehatan Provinsi Sumatera Barat (DINKES SUMBAR) tahun 2009 didapatkan sekitar 2700 orang mengalami insiden fraktur, $56 \%$ penderita mengalami kecacatan fisik, $24 \%$ mengalami kematian, $15 \%$ mengalami kesembuhan dan $5 \%$ mengalami gangguan psikologis atau depresi terhadap adanya kejadian fraktur. ${ }^{4}$ 
Fraktur dapat disebabkan oleh keadaan patologis selain dari faktor traumatik. Fraktur pada tulang lemah yang disebabkan oleh trauma minimal disebut dengan fraktur patologis. Penyebab tersering fraktur patologis pada femur proksimal adalah osteoporosis. $^{5}$

Jenis fraktur femur mempunyai insiden yang tinggi diantara fraktur tulang lain dan fraktur femur paling sering terjadi pada batang femur $1 / 3$ tengah. Fraktur femur lebih sering terjadi pada laki-laki daripada perempuan dengan umur dibawah 45 tahun dan sering berhubungan dengan olahraga, pekerjaan atau kecelakaan. ${ }^{6}$

\section{METODE}

Penelitian ini telah dilaksanakan di Bagian Rekam Medik R.S Dr.M.Djamil, Padang pada bulan August 2015 sampai September 2015. Penelitian ini bersifat deskriptif menggunakan data sekunder pasien yang dirawat di Poli Bedah Orthopedi dari tahun 20102012 yang memenuhi kriteria inklusi yaitu umur, jenis kelamin, lokasi fraktur, jenis fraktur, jenis penatalaksanaan fraktur femur dan faktor penyebab fraktur. Data diolah secara manual dan disajikan dalam bentuk tabel distribusi frekuensi.

\section{HASIL}

Tabel 1. Distribusi fraktur femur berdasarkan jenis kelamin

\begin{tabular}{lcc}
\hline Jenis Kelamin & Frekuensi & $\%$ \\
\hline Perempuan & 33 & 28,4 \\
Laki- laki & 83 & 71,5 \\
\hline Total & 116 & 100
\end{tabular}

Tabel 1 menunjukkan bahwa kasus fraktur femur yang terbanyak ditemukan pada jenis kelamin laki-laki sebanyak 83 orang $(71,5 \%)$. Laki- laki lebih aktif dan lebih banyak melakukan aktivitas daripada perempuan. Aktivitas di luar rumah untuk bekerja mempunyai risiko lebih tinggi mengalami cedera. Fraktur femur lebih banyak terjadi kerana kecelakaan lalu lintas. Tingginya kasus fraktur akibat kecelakaan lalu lintas pada laki-laki dikarenakan laki-laki mempunyai perilaku mengemudi dengan kecepatan yang tinggi sehingga menyebabkan kecelakaan yang lebih fatal dibanding perempuan. ${ }^{2}$
Tabel 2. Distribusi fraktur femur berdasarkan usia

\begin{tabular}{lrr}
\hline Usia (tahun) & Frekuensi & $\%$ \\
\hline $0-5$ & 1 & 0,86 \\
$5-11$ & 8 & 6,89 \\
$12-16$ & 14 & 12,06 \\
$17-25$ & 36 & 31,03 \\
$26-35$ & 17 & 14,65 \\
$36-45$ & 14 & 12,06 \\
$46-55$ & 11 & 9,48 \\
$56-65$ & 6 & 5,17 \\
$>65$ & 9 & 7,75 \\
\hline Total & 116 & 100
\end{tabular}

Tabel 2 menunjukkan bahwa fraktur femur banyak terjadi pada usia 17 - 25 tahun sebanyak 36 orang $(31,03 \%)$. Pada kelompok usia muda, mereka lebih banyak melakukan aktivitas yang berat daripada kelompok usia tua. Aktivitas masyarakat usia muda di luar rumah cukup tinggi dengan pergerakan yang cepat dapat meningkatkan risiko terjadinya benturan atau kecelakaan yang menyebabkan fraktur. Tulang yang mendapatkan tekanan terus menerus di luar kapasitas dapat mengalami keretakan tulang. ${ }^{2}$ Bagi penderita usia kelompok tua, massa tulang yang rendah cenderung mengalami fraktur. Dengan benturan kecil, dapat menyebabkan fraktur kerana massa tulang yang rendah tidak mampu menahan daya benturan. Pengurangan massa tulang jelas pada kelompok usia tua, konsumsi kalsium dan vitamin $\mathrm{D}$ dapat menguatkan jaringan tulang. ${ }^{5}$

Tabel 3. Distribusi fraktur femur berdasarkan lokasi fraktur femur

\begin{tabular}{lcc}
\hline Lokasi Fraktur & Frekuensi & $\%$ \\
\hline Proksimal & 40 & 34,4 \\
Medial & 57 & 49,1 \\
Distal & 19 & 16,3 \\
\hline Total & 116 & 100 \\
\hline
\end{tabular}

Tabel 3 menunjukkan bahwa lokasi fraktur femur banyak terjadi di bagian medial femur sebanyak 57 kasus $(49,1 \%)$. Fraktur pada medial femur terjadi akibat kecelakaan lalu lintas, kerana posisi femur sejajar dengan bumper mobil sehingga ketika kecelakaan, medial femur yang sering terkena. Fraktur collum femur atau pada bagian proksimal dapat disebabkan oleh trauma langsung apabila penderita jatuh dengan posisi miring yaitu daerah trochanter 
mayor langsung terbentur dengan benda keras ataupun disebabkan oleh trauma tidak langsung yaitu karena gerakan exorotasi yang mendadak dari tungkai bawah.Kebanyakan fraktur collum femur terjadi pada wanita (60 tahun keatas) dimana tulangnya sudah mengalami osteoporosis. Trauma yang biasa dialami seperti jatuh terpeleset dikamar mandi. ${ }^{7}$

Tabel 4 menunjukkan bahwa jenis fraktur yang sering terjadi pada fraktur femur adalah fraktur tertutup iaitu sebanyak 97 kasus (83,6 \%).Fraktur tertutup adalah frakturnya yang tidak berhubungan dengan dunia luar dimana kulitnya utuh.Fraktur batang femur biasanya terjadi karena trauma langsung, patah pada daerah ini dapat menimbulkan perdarahan yang cukup banyak, mengakibatkan penderita jatuh dalam syok, salah satu klasifikasi fraktur batang femur dibagi berdasarkan adanya luka yang berhubungan dengan daerah yang patah seperti fraktur tertutup dan fraktur terbuka. ${ }^{2}$ Pergerakan laju atau impact menyebabkan fragmen tulang terdorong ke fragmen tulang lain menyebabkan fraktur tertutup.

Tabel 4. Distribusi fraktur femur berdasarkan jenis fraktur femur

\begin{tabular}{lcc}
\hline Jenis Fraktur & Frekuensi & $\%$ \\
\hline Terbuka & 3 & 2,58 \\
Grade I & 3 & 2,58 \\
Grade II & 13 & 11,2 \\
Grade III & & \\
Tertutup & 97 & 83,6 \\
\hline Total & 116 & 100 \\
\hline
\end{tabular}

Tabel 5 menunjukkan bahwa tindakan operasi yang terbanyak dilakukan pada kasus fraktur femur iaitu sebanyak 92 kasus (79,3\%). Terapi konservatif meliputi proteksi dengan mitela atau bidai dan pemasangan traksi Sedangkan terapi operatif terdiri dari reposisi terbuka, fiksasi internal, reposisi tertutup dengan kontrol radiologis diikuti fiksasi interna. ${ }^{8}$ Pada saat ini metode penatalaksanaan yang paling banyak keunggulannya adalah pembedahan. Metode ini adalah fiksasi interna dan reduksi terbuka. Pada umumnya insisi dilakukan pada tempat yang mengalami cedera dan diteruskan sepanjang bidang anatomik menuju tempat yang mengalami fraktur. Fraktur kemudian direposisi dengan tangan agar menghasilkan posisi yang normal kembali.

Tabel 5. Distribusi fraktur femur berdasarkan tindakan yang dilakukan pada fraktur femur di poli bedah orthopedi

\begin{tabular}{lcc}
\hline Tindakan & Frekuensi & $\%$ \\
\hline Konservatif & & \\
Pemasangan gips & 3 & 2,70 \\
Pemasangan & & \\
traksi & 21 & 18,91 \\
Operasi & & \\
ORIF & 86 & 77,47 \\
OREF & 1 & 0,9 \\
& & \\
\hline Total & 111 & 100 \\
\hline
\end{tabular}

Sesudah direduksi, fragmen-fragmen tulang ini dipertahankan dengan alat-alat ortopedi seperti plate and screw. ${ }^{8}$ Tindakan ORIF adalah tindakan pembedahan untuk memanipulasi fragmen-fragmen tulang yang patah/fraktur sedapat mungkin kembali seperti letak asalnya. internal fiksasi biasanya melibatkan penggunaan plat, sekrup, paku untuk mempertahankan fragmen tulang dalam posisinya sampai penyembuhan tulang yang solid terjadi. Tindakan ORIF lebih banyak dilakukan kerana memiliki keuntungan seperti reduksi akurat, stabilitas reduksi tinggi. Berkurangnya kebutuhan alat immobilisasi eksternal, penyatuan sendi yang berdekatan dengan tulang yang patah menjadi lebih cepat, rawat inap lebih singkat dan dapat lebih cepat kembali ke kehidupan aktivitas normal. ${ }^{9}$ Tindakan OREF adalah reduksi terbuka dengan fiksasi internal di mana prinsipnya tulang ditransfiksasikan di atas dan di bawah fraktur, kawat ditransfiksi di bagian proksimal dan distal kemudian dihubungkan satu sama lain dengan suatu batang lain. Tindakan OREF diindikasi pada fraktur terbuka grade II dan III, fraktur terbuka yang disertai hilangnya jaringan atau tulang yang parah, fraktur yang disertai dengan kerusakan pebuluh darah dan saraf.Keuntungan dari fiksasi eksternal adalah memberi kenyamanan bagi pasien, mobilisasi awal dan latihan awal untuk sendi di sekitarnya. 
Tabel 6. Distribusi fraktur femur berdasarkan faktor penyebab fraktur femur

\begin{tabular}{lcc}
\hline Faktor Penyebab & Frekuensi & $\%$ \\
\hline Cedera patologis & 8 & 6,89 \\
jatuh terduduk & 11 & 9,48 \\
jatuh miring & & \\
$\begin{array}{l}\text { Cedera traumatik } \\
\text { Kecelakaan lalulintas }\end{array}$ & 97 & 83,6 \\
\hline Total & 116 & 100 \\
\hline
\end{tabular}

Tabel 6 menunjukkan bahwa penyebab fraktur femur terbanyak terjadi karena cedera traumatik yaitu kecelakaan lalu lintas sebanyak 97 kasus (83,6 \%). Faktor lingkungan seperti kondisi jalan raya, permukaan jalan yang tidak rata atau berlubang, serta pengenderaan cepat dan tidak berhati hati dan tidak mematuhi rambu lalu lintas dapat menyebabkan kecelakaan yang menimbulkan fraktur. Bagi kelompok usia tua, mereka mempunyai postur tubuh yang kurang baik mengakibatkan mereka hilang stabilitas sehingga mudah terjatuh. Pada lingkungan rumah tangga, kondisi lantai licin dapat mengakibatkan peristiwa jatuh terutama pada kelompok usia tua yang cenderung mengalami fraktur bila terjatuh. ${ }^{3}$

\section{SIMPULAN}

Distribusi fraktur femur yang dirawat di Rumah Sakit Dr.M.Djamil, Padang menunjukkan mayoritas fraktur femur terjadi pada laki-laki yang berusia 17-25 tahun dan penyebab terbanyak adalah cedera traumatik seperti kecelakaan. Fraktur femur banyak terjadi di bagian medial femur dan merupakan fraktur tertutup.

\section{DAFTAR PUSTAKA}

1. Saunders. Dorland's pocket medical dictionary. Edisi ke-28; 2009.

2. Sjamsuhidajat $\mathrm{R}$, de Jong. Buku ajar ilmu bedah. Edisi ke-7. Jakarta: EGC; 2007.hlm.1039-42.

3. World Health Organization. World health statistics 2010. 2010 (diunduh 14 Juni 2012). Tersedia dari: URL: HYPERLINK

http://www.who.int/whosis/whostat/2010/en/.

4. Dinas Kesehatan Provinsi Sumatera Barat. Profil dinas kesehatan Provinsi Sumetera Barat. 2010 (diunduh 14 Juni 2012). Tersedia dari: URL: HYPERLINK http://dinkes.sumbarprov.go.id

5. Graham A, Solomon L, Kartini A. Apley's sytem of orthopaedics and fractures. Edisi ke-7. Jakarta: Widya Medika,2012.hlm.238-45.

6. Mansjoer A. Kapita selekta kedokteran.Edisi ke-2. Jakarta: Media Aesculapius; 2000.hlm.45-7.

7. Darmojo RB. Buku Ajar Geriatri. Edisi ke-3. Jakarta: Balai Penerbit Fakultas Kedokteran Universitas Indonesia; 2006.

8. Rasyad C. Penghantar ilmu bedah orthopedi. Edisi ke-3. Makassar: Bintang Lamumpatue; 2003.hlm.407-9.

9. Black, Joyce M. Medical surgical nursing. Philadelpia: WB Saunders Company;2009.hlm.1-9. 